\title{
Social networks and environmental management at multiple levels: soil conservation in Sumatra
}

\author{
Petr Matous $^{1,2}$
}

\begin{abstract}
Many agrarian communities in developing countries suffer from insufficient productivity and use farming practices that deteriorate the environment both locally and globally. Research suggests that social networks play a role in environmental management, different studies emphasize different aspects of network structures, and the implications of the scales at which networks operate are not explicitly discussed. Here, I ask what types of social structures in farmer networks are conducive to environmental protection and agricultural productivity enhancement, and I show that the answer depends on the scale of the investigation. Using original data representing 16 farmer groups comprising 315 households and 1575 information-sharing links, I analyzed the structure of farmers' social connections in relation to their soil conservation and productivity-enhancing practices, assessed through their usage of organic and chemical fertilizers. Furthermore, I conducted qualitative interviews with 25 stakeholders from different levels of the agricultural system to gain additional insights into the drivers of farmers' behaviors. The quantitative analysis distinguishes the effects of intraand extra-group links and reciprocity at the household and group levels. Fixed-effects logistic regression was applied at the household level to examine farmers' soil management practices. At the collective level, I used linear regression to estimate the proportion of adopters for each soil management practice. A lack of education and a lack of extra-group links are associated with unproductive practices, and a lack of reciprocity is associated with a lack of conservation efforts at both the household and collective levels. Dense intra-group links have opposite effects at the two levels. Whereas links within the farmer groups are associated with unproductive soil management by households, these links are associated with productivity maximization at the collective level. Qualitative interviews showed that farmers who opt for organic fertilizers do so partially because of pressure from global traders, mediated through external links and amplified by dense and reciprocal relations within their groups. The results highlight the need for environmental management policies to be based on research at multiple scales and demonstrate that, counter-intuitively, increasing global economic interconnectivity may, in some cases, stimulate the adoption of conservation practices via local social networks.
\end{abstract}

Key Words: community-based management; cross-level interactions; fertilizers; social networks; soil management

\section{INTRODUCTION}

Agricultural production is a major driver of global environmental change (Tilman et al. 2001). The adoption of appropriate conservation practices, i.e., closing the nutrient cycle involving soil, crops, and livestock in rapidly expanding farming regions of the developing world, is urgently needed but difficult to achieve (Tilman et al. 2001). The vicious cycle of farmers striving for higher yields by employing uninformed methods that degrade soil quality, damage natural ecosystems, and consequently decrease productivity must be broken to improve living conditions for much of humanity (Lal 2004). Globalization further exacerbates the pressure on stressed local ecosystems because global demand for local produce may overwhelm the capacity of locally evolved organizations and institutions (Brondizio et al. 2009). As Young et al. (2006) describe, as increasing numbers of urban residents from the growing global middle class must have their coffee first thing in the morning, ecosystems in coffee-growing areas in Indonesia, Guatemala, Honduras, and Brazil are under increasing stress.

It has been recognized that for the successful management of the environment in increasingly human-dominated ecosystems, integrating social sciences and natural sciences is necessary (Dietz et al. 2003, Liu et al. 2007). However, most of the work on humanand nature-coupled systems has been theoretical because the complex webs of interactions in these systems are difficult to identify in empirical, and particularly in quantitative, assessments
(Young et al. 2006). Promisingly, in recent years, researchers have begun to conceptualize these complex relationships successfully as empirically measurable networks (Johnson et al. 2009, PahlWostl 2009, Prell et al. 2009, Reed et al. 2009, Crona and Bodin 2010, Bodin and Tengö 2012, Prell 2012, Dell'Apa et al. 2013, Bergsten et al. 2014, Brockhaus and Di Gregorio 2014, Carien De Villiers et al. 2014, Deehr et al. 2014, Lubell et al. 2014, Moeliono et al. 2014) and to quantify how social networks may influence environmental behavior such as farmers' practices (Solano et al. 2003, Hoang et al. 2006, Isaac et al. 2007, 2014, Schneider et al. 2009, Conley and Udry 2010, Bodin and Prell 2011, Spielman et al. 2011, Isaac 2012, Matouš et al. 2013b, Matous and Todo 2015). However, it is less widely recognized that the effectiveness of diverse network structures may depend on the scale at which environmental problems are approached (Lebel et al. 2010). For example, it may be found through an actor-level analysis that better-informed individual fishermen with more information-sharing links have more fishing success (Turner et al. 2014). However, without a network-level analysis, we may not notice that communities with more information links may be worse off overall because their members may be more successful in depleting local fisheries. Alternatively, whereas a family with prominent social connections within a community may have privileged access to limited natural resources, highly interconnected communities may have a better capacity to prevent a single family from excessively consuming shared resources.

${ }^{1}$ University of Tokyo, ${ }^{2}$ University of Sydney 
Thus, network links may be associated with natural-resourcedepleting behavior at one level and resource conservation at another.

It is necessary to understand better the multi-level structure of interactions between social systems and ecosystems (Brondizio et al. 2009, Engle and Lemos 2010, Sikor et al. 2010). However, navigating issues of scale presents one of the greatest challenges to the union between natural science and social science empirical research. Although the importance of scale has always been emphasized in the natural sciences, the issue of scale has traditionally been less developed in the social sciences (Tilly 1989, Coleman 1990, Gibson et al. 2000). In empirical social network studies, statistical analysis is typically carried out at the node level, and available data sets of offline interactions rarely contain a sufficient number of whole comparable networks for a rigorous analysis at the collective level. However, when an individual's behavior has an influence on other network members, the final scaled-up outcome is not a simple sum of the individual outcomes, and larger scale policies based on individual- or household-level studies may thus be counterproductive (Janssen and Ostrom 2006). This scale mismatch may be particularly pertinent when dealing with issues that have opposing individual and collective consequences (e.g., farming techniques that bring private gains but have negative externalities) or when global forces influence local processes through increasingly strong economic links.

Here, I examine how social networks are related to the adoption of soil conservation and productivity-enhancing practices by smallholder farmers. Using an original, unique data set of 16 randomly selected coffee- and cocoa-growing farmer groups in Sumatra, I illustrate the convergent and divergent characteristics of networks at the household and collective levels in relation to the usage of organic and chemical fertilizers. I also use qualitative interviews to shed light on the higher level influences on this dynamic.

\section{THEORETICAL FRAMEWORK}

I begin by defining the terminology of scales and explaining its relevance in connection to co-management theories. Furthermore, I review the theoretical relevance of intra- and extra-group relationships for environmental management from the perspective of social network theory. I then introduce the categorization of pro-environmental and productivity-enhancing soil management strategies applied in this research framework.

\section{Scales and levels}

The terms "level" and "scale" are closely related but not identical. Whereas scale refers to an analytical dimension, level refers to a location along the scale (Gibson et al. 2000, Cash et al. 2006, Brondizio et al. 2009). While the choice of agricultural techniques is made at the household level, it may be influenced by the whole community or higher level institutions. This cross-level interaction can be mediated through knowledge-sharing social networks linking the household with the farmer group and with the wider region. My quantitative analysis is carried out at two levels: the level of the individual network actors (i.e., households), and the collective level of entire farmer group networks. These two levels are part of a constitutive nested hierarchy. The connection between the farmer groups and higher level institutions in this constitutive hierarchy is further explored through qualitative interviews with representatives of each level.

\section{Co-management and social learning networks}

The cooperation between the groups of local resource users and higher level institutions has come to the forefront in the literature and practice of environmental management, and the role of local communities in reflective knowledge generation within learning networks has been particularly emphasized (Kapoor 2001, Plummer and Fitzgibbon 2004, Carlsson and Berkes 2005, Fraser et al. 2006, Berkes 2009, Pahl-Wostl 2009, Dyer et al. 2014). The environmental co-management literature often stresses the importance of bringing together different actors as well as the importance of networks that span multiple levels of social organization for accessing diverse information, learning, and engagement with the external world (Berkes 2009). However, it is not self-evident whether knowledge generated through external cooperation is always internally shared and accepted, nor whether the relationships with higher level institutions necessarily stimulate social learning and broad pro-environmental action at the collective level. I hypothesize that extra- and intra-group networks play specific roles in the process.

\section{Internal and external links at different levels}

Studies of small-scale societies have demonstrated that many communities are successful in managing their environment (Ostrom 1990). However, there is substantial variation in outcomes from one setting to another, and recent research suggests that this variation may be related to the network structure of communities (Bodin and Crona 2009). I next review the theoretically relevant aspects of networks considered here.

The sociological literature emphasizes the difference between links within and outside (variously defined) groups (Granovetter 1973, Burt 1995, Erickson 2001, Lin 2001). This internal vs. external dichotomy is theorized by different influential authors using different terms, e.g., bridging and bonding relationships, embedded and autonomous relationships, and integrating and linking relationships (Woolcock 1998). In empirical research, the type of links in focus is related to the chosen analytical strategy. Studies in which the main unit of analysis is a network actor provide different insights from studies in which the main unit of analysis is a single network.

Inhabitants of rural communities in developing countries tend to have relatively localized relationships, but increasing economic integration and infrastructure development are catalyzing the creation of long-distance links and the emergence of complex higher level network structures (Young et al. 2006, Brondizio et al. 2009, Matous et al. 2011, 2013a, 2014). From an individual viewpoint, the links reaching outside social cliques are considered the most important for the diffusion of innovative techniques. Hundreds of empirical studies of the diffusion of innovations report that individuals unbound by local social structures and individuals with extensive relationships to diverse social groups and institutions tend to be early adopters of progressive technologies, whereas individuals whose lives are bound within their own cliques tend to be more reluctant to change their habits (see review by Rogers 2003). On a general level, the "strength of weak ties" principle explains why relationships reaching outside 
of one's immediate social circle, which are more likely to be weak, are crucial for access to such innovative methods (Granovetter 1973).

From this individualistic viewpoint, an "excess of community" can be a burden. Instrumental links extending beyond one's own group may be difficult to create if intra-community relationships are highly demanding (Woolcock 1998). High social integration characterized by ethnic loyalties and familial attachments may discourage linkage and concern for issues of wider societal importance (Woolcock 1998). Farmers who are strongly connected within their community may be less receptive to external sources of information (Matouš et al. 2013b), and information available within isolated "bonding networks" may not always be recommendable from the point of view of external experts (Wolf et al. 2010).

Studies at the collective level are concerned with how different network structures lead to the different ways that things are done in different communities (Rodela 2011). From the collective-level network perspective, the importance of densely woven webs of relationships within communities is emphasized for the governance of common resources and enforcement of norms (Dietz et al. 2003, Pretty 2003). Coleman's (1988) social capital theory highlights the necessity of closure, i.e., closed, locally dense network structures with reciprocal relations, for the development of social norms. A dense set of associations within a group is ordinarily a result of (not necessarily conscious) efforts of small numbers of people, and Coleman (1988) notes that these types of social structures do not primarily benefit the persons who bring them about but benefit all members of the structure. Cohesive networks of relationships among rural households may potentially increase the resilience of rural communities to environmental shocks (Trærup 2012, Prior and Eriksen 2013), and several studies warn that creating external links may destroy local social networks (Colten et al. 2012, McCormick 2012). Linkage without integration is considered to be the hallmark of modernization, leading to norm deterioration (Woolcock 1998).

Although the importance of community connectedness for environmental governance has been emphasized (Pretty and Ward 2001), arguments regarding the outcomes of networks at the collective level have remained relatively untested statistically because of the difficulty involved in collecting a sufficient number of networks to enable rigorous comparisons. Another problem is that most studies treat human-environment interactions as selfcontained and disregard links to the outside world for purposes of analysis (Brondizio et al. 2009). This approach is often analytically convenient and allows for simpler data gathering, but in reality, even remote communities do not exist in a vacuum. The ongoing growth of interdependency within resource-use systems amplifies the need to recognize interconnections among local communities and between local communities and higher level institutions (Cheong 2012).

I aim to identify empirically the role of intra- and extra-group links for farmers' soil management strategies at both the actor and collective levels. I next explain how patterns of adoption of chemical and organic fertilizers in different farmer groups are used to categorize such strategies.

\section{Usage of chemical and organic fertilizers}

In predominantly agrarian societies in developing countries, increases in environmentally sustainable agricultural productivity could directly improve the well-being of large populations. However, the global South is trapped in a vicious cycle in which "poor farmers have passed on their suffering to the land through extractive practices. They cultivate marginal soils with marginal inputs, produce marginal yields, and perpetuate marginal living and poverty" (Lal 2004:1625). To feed the growing global population without an extensive expansion of cropland, agricultural productivity in developing countries must be increased (Tilman et al. 2001), which will require increased inputs of nutrients (Matson et al. 1997). Without nutrient addition, land cultivation leads to soil degradation and decreased yield, necessitating the conversion of more forests to agriculture (Liu et al. 2007), which is a serious problem, particularly in Indonesia (Hansen et al. 2009).

\section{Chemical fertilizers}

The use of inorganic, industrially produced fertilizers was a key factor enabling the increase in food production in the 20th century. However, the contribution of chemical fertilizers to the alteration of the Earth's biogeochemical cycles has caused alarm (Matson et al. 1997, Vitousek et al. 1997). In Indonesia, mineral NPK fertilizers (supplying nitrogen, phosphorus, and potassium) and industrial urea (supplying nitrogen) are produced and widely distributed by state-owned companies at regulated prices (FAO 2005). Inputs of N, P, and K can increase crop yields, but extensive application may have negative side effects for the local and global environments. At the farm level, long-term intensive application of chemical fertilizers can deteriorate soil quality and decrease productivity. At the regional level, excessively supplied $\mathrm{N}$ may enter the water cycle and cause hypoxia and eutrophication, as well as threaten biodiversity in adjacent marine areas (HufnaglEichiner et al. 2011). Globally, the production of chemical fertilizers depletes nonrenewable resources and emits greenhouse gases that cause global climate change (Tilman et al. 2001, Cordell et al. 2009, Scholz and Wellmer 2013). Alteration of the N cycle has increased the levels of nitrous oxide globally (Vitousek et al. 1997). Because of these negative local and global environmental effects, influential publications have called for decreases in the amounts of chemical fertilizers used by increasing the application of organic alternatives (Matson et al. 1997).

\section{Organic fertilizers}

The importance of organic inputs such as animal manure for maintaining soil fertility in the Indonesian tropical climate has been recognized (FAO 2005). Animal manure based fertilizers slowly and consistently release $\mathrm{N}$ to the cultivated soil, which would otherwise be released into the ecosystem in an unproductive way (Seufert et al. 2012). Such amendments also supply organic material and other nutrients that are not included in NPK fertilizers or urea. At the plot level, the addition of manure and organic materials conserves soil and water, improves soil structure, prevents erosion, reduces nutrient leaching, strengthens the mechanisms of elemental cycling, and supports biodiversity in the soil (Matson et al. 1997, Cassman 1999). Increasing the soil organic matter content is often the principal means by which $\mathrm{N}$, $\mathrm{P}$, and $\mathrm{K}$ are held in the soil (Breman et al. 2001). At the village or regional levels, soil organic carbon is a biomembrane that filters 
pollutants, reduces sediment loads in rivers, decreases hypoxia in coastal ecosystems, and degrades contaminants. At the global level, organic fertilizers are a sink for atmospheric carbon dioxide and methane (Lal 2004). By reducing the rate of enrichment of atmospheric carbon dioxide, organic fertilizers have the potential to offset fossil fuel induced global environmental change (Lal 2004). If manure is used instead of synthetic N, N emissions from cropland and nitrous oxide emissions from animal management are also reduced (Scott et al. 2002).

\section{Soil management strategies}

I examine the usage of chemical and organic fertilizers according to the following framework. Instead of dosage, I focus on adoption vs. nonadoption, which data are relevant and reliably obtainable. Optimal dosages are not agreed upon in Indonesia, and exact fertilizer amounts are difficult to survey (FAO 2005). Whereas technology adoption studies typically focus on the adoption of separate technologies (Rogers 2003), I consider the adoption of chemical and organic fertilizers and their combination. The two types of fertilizers can be adopted in any of the following four combinations: no fertilizers ("nonusers"), only chemical, only organic, and both types combined ("combined users"). The last category, a combination of mineral fertilizers with locally available organic soil amendments, is typically recommended to maximize yield (Matson et al. 1997, Yamoah et al. 2002, FAO 2005) because it is more difficult to provide sufficient nutrients with organic fertilizers alone (Seufert et al. 2012).

Farmers' soil management strategies may not be based only on the advice obtained through the identified network partners. People's behavior may be influenced by the perceived social norms of their group, even if they are not aware of it (Keizer et al. 2008, Nolan et al. 2008, Abrahamse and Steg 2013, Kashima et al. 2013). Humans not only display general tendencies toward solidarity with their peers, but also strive to express their higher status to those of lower social standing (Gee 2013). Farmers may unconsciously adjust their practices to align with peers of similar social characteristics and may select different practices from those of individuals with whom they disassociate (McPherson et al. 2001, Rogers 2003). Therefore, I also consider decision makers' socioeconomic status and the socioeconomic status of others in their farming group.

\section{METHODS}

\section{Surveyed farmer groups and data gathered}

Real-world social network surveys are demanding, particularly among low-density populations in low-capacity contexts. Consequently, most environmental network studies focus on only one or a small number of networks. Such data enable the analysis of the relation between the position of actors (which can represent individuals, households, or organizations) in the network and an environmental outcome at the node level. Alternatively, the whole network structure can be discussed as a case study (e.g., Brummel et al. 2012, Weiss et al. 2012). However, social networks vary across the landscape (Liu et al. 2007). To uncover the systematic tendencies linking whole network structures and collective-level outcomes, data sets containing a larger number of comparable networks are required.

My research is based on a unique data set of networks inside and outside of 16 farmer groups. The data were gathered from farmer groups in two sub-districts of Tanggamus Regency, Lampung Province, Sumatra: Sumberejo and Pulau Panggung. These subdistricts are known for coffee and cocoa production. Sumatra is one of the outer Indonesian islands, which constitute $>90 \%$ of Indonesia's land area but host fewer than one-half of the national population. Soil fertility on the outer islands is generally relatively low (FAO 2005).

The farmer groups are an important component of information dissemination and the administration of Indonesian agricultural policies. Although some farmer groups have existed informally for decades, they were formalized mainly in 2007 and 2008 in response to a new governmental policy regarding the provision of official information, financial support, subsidized inputs, and equipment. According to information from local government officials, government support to farmers, such as fertilizers or information about product competitions and training, is now channeled only through registered organizations. The typical size of a farmer group is approximately 20 households. These organizations have regular monthly meetings held on a rotational basis in the members' homes. Large villages have more than one farmer group, but each household typically joins the nearest group or the group to which their friends belong (Fig. 1). Multiple memberships are not allowed. Sumatran villages, and thus farmer groups, tend to be ethnically segregated owing to a legacy of massive government-led group migration programs from other parts of Indonesia in previous generations.

A fixed-form, face-to-face administered questionnaire was targeted at all household heads in 16 coffee- and cocoa-producing farmer groups. The farmer groups were randomly selected from among all 36 coffee and cocoa groups present in the two subdistricts. Only coffee- and cocoa-producing farmer groups were targeted to enable valid comparisons among farmers who grow similar crops. The 16 selected farmer groups listed 398 households as members in 2008, when the lists were first compiled by the government. During the survey in September 2012, our survey team managed to access and administer the questionnaire to 315 of the farming group member households.

Self-identified household heads were asked to name persons from whom they received agricultural information. Specifically, the English translation of the network prompt is: "Please list all people you can recall from outside this household from whom you seek advice, from whom you can learn, or who can generally provide useful information regarding farming practices." In total, 1575 information-sharing links were elicited. The respondents could name anyone inside or outside the farmer group. External information sources include nonfarmers such as agricultural experts working for the local government.

A common approach in empirical social-ecological network studies is to "symmetrize" the obtained links. If a person or an organization A mentioned B as a network partner, B mentioned A, or both mentioned each other, any of these cases would be treated as a link between A and B. However, the direction of the links can be used to measure reciprocity, a theoretically important factor in the community management of natural resources (Pretty and Ward 2001). If A names B as an important information partner but B does not mention A, the relationship may be of a hierarchical nature. In contrast, if both name each other (despite recall problems inherent to survey research), the relationship may be reciprocal and, possibly, stronger. Here, I distinguish the link 
Fig. 1. Geographical distribution of the sample population. Each letter represents one household, and households belonging to the same farmer group are represented by the same letter and color. Map was created using $\mathrm{R}(\mathrm{R}$ Development Core Team 2008).

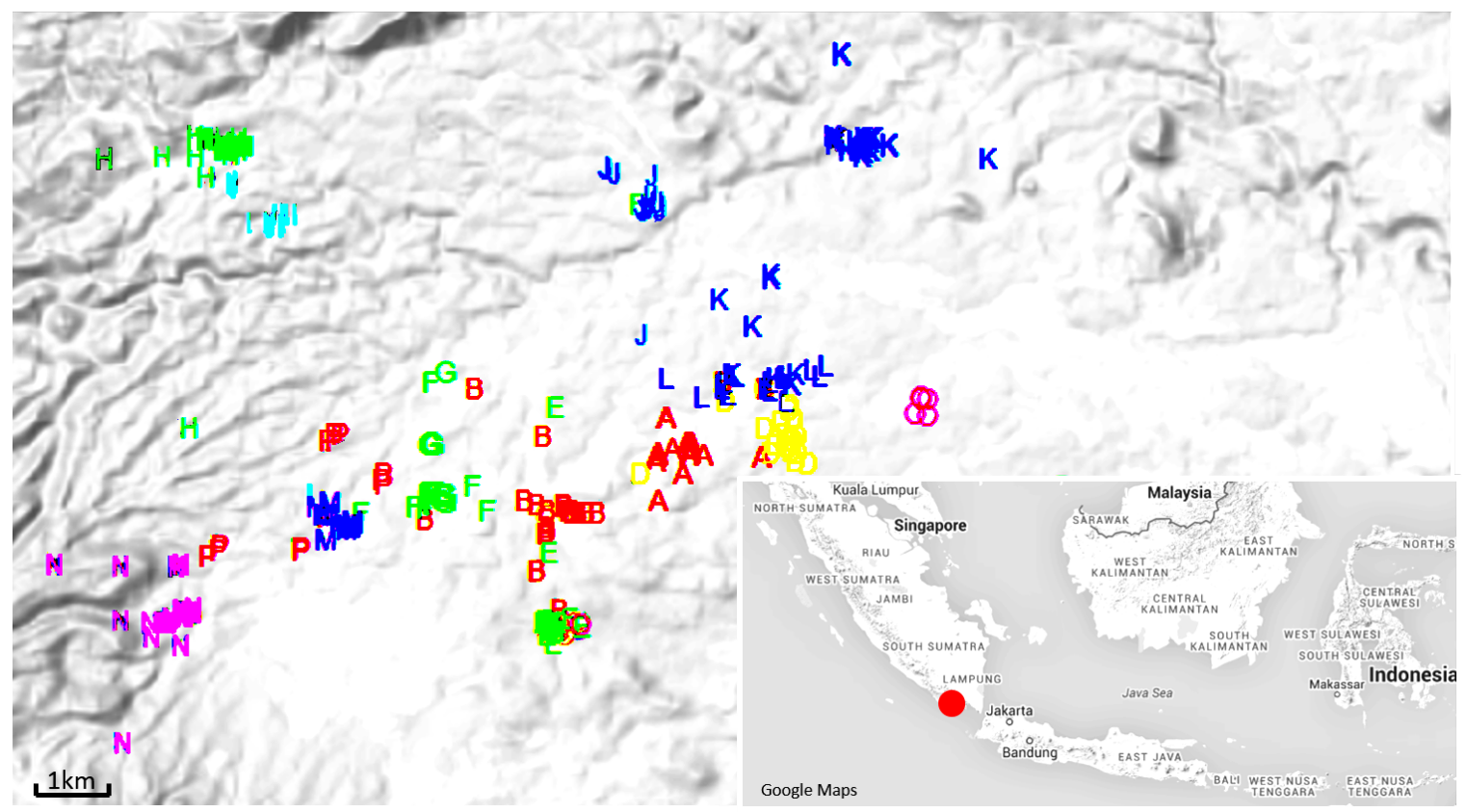

direction and consider the number of intra-group reciprocated links for each household and each farmer group. This measure is not available for extra-group links because I do not know whether external links are reciprocated by the external informants outside of the survey. Thus, the reciprocity variables provide information about the character of the internal networks only.

Network characteristics may be correlated with confounding fundamental household or community characteristics. For example, larger agricultural producers may be more central in local social networks because of their affluence; this affluence may also allow these producers to make risky transitions to new technologies. Observing an association between farmers' relationships and their production techniques without controlling for the most basic economic characteristics may thus be misleading. Therefore, in addition to network characteristics, I also consider wealth, as approximated by the area of cultivated land and whether someone in the household has received formal education. Specifically, I used a dummy variable indicating whether anyone in the household had finished primary education. This threshold at which education has a significant effect on the adoption of fertilizers was found inductively (Table 1). Education conceptualized as a continuous variable did not have a statistically significant effect in the models. The data suggest that further education beyond the primary level does not make a linear contribution to the understanding and adoption of fertilizers.

Geographical data such as altitude and the estimated distances from the nearest paved road, unpaved road, and nearest neighbor were not statistically significantly associated with soil management strategies (separately or in any combination) and did not improve the fit of the models (all $P>0.1$ ). The lowest significance values were associated with the estimated distance from the nearest paved road (positive relation between distance and combined fertilizer usage: $P=0.12$; negative relation between distance and usage of chemical fertilizer: $P=0.16$ ). It is plausible that farmers who live farther away from paved roads are more likely to substitute chemical fertilizers partially with organic fertilizers, but there is not sufficient statistical confidence for any of the geography-related results. Thus, I do not discuss geography further here.

Between 2012 and 2014, I also conducted field observations and qualitative interviews with 25 farmers from 12 groups, two of the highest-ranked officials at the Forestry and Crop Estate Service Department of the Tanggamus district, and four extension agents. The interviews took a maximum of $2 \mathrm{~h}$, were simultaneously interpreted between Indonesian and English, and provided additional insights from different levels of the agricultural systems regarding the drivers of farmers' soil management strategies. The discussed topics included the priorities of the local government, the functioning of the farmer groups, and the farmers' environmental concerns and perceptions of fertilizers.

\section{Analytical strategy}

All farmer groups have compulsory regular meetings during which farming methods are discussed and attendance is registered. Thus, in theory, every farmer may learn from any other farmer in his or her group. When the research assistants asked the farmers to name from whom they can learn, some interviewees' first answer was "everyone." When they were reminded to name specific persons, they focused on the most important communication links. However, these elicited links are clearly not the only communication channels through which practices may 
Table 1. Household-level description of network measures.

\begin{tabular}{|c|c|c|c|c|c|}
\hline Variable & $\begin{array}{c}\text { Number of valid } \\
\text { observations }\end{array}$ & Mean & $\begin{array}{l}\text { Standard } \\
\text { deviation }\end{array}$ & Minimum & Maximum \\
\hline Internal links & 315 & 3.7 & 3.6 & 0 & 19 \\
\hline External links & 315 & 1.4 & 1.7 & 0 & 10 \\
\hline Area of cultivated land (ha) & 308 & 1.0 & 0.8 & 0 & 5 \\
\hline Someone in household finished primary school (yes $=1)$ & 315 & $91 \%$ & & & \\
\hline Household altitude (m) & 309 & 422 & 108 & 245 & 688 \\
\hline Estimated walking time to nearest paved road (min) & 271 & 3.9 & 7.4 & 1 & 120 \\
\hline Uses no fertilizers $($ yes $=1)$ & 315 & $10 \%$ & & & \\
\hline Uses only chemical fertilizers (yes $=1$ ) & 315 & $18 \%$ & & & \\
\hline Uses only organic fertilizers $($ yes $=1)$ & 315 & $17 \%$ & & & \\
\hline Combined use of chemical and organic fertilizers $($ yes $=1$ ) & 315 & $55 \%$ & & & \\
\hline
\end{tabular}

spread in these cases. Therefore, I do not model soil management practices in analogical ways such as modeling a liquid flowing through a pipework, viruses spreading through social contact, or goods moving through supply chains. To examine quantitatively whether the studied practices spread at the household level, specifically through the elicited links, longitudinal data and different analytical methods are necessary (see Matous and Todo 2015). Examining diffusion between networks at the collective level is even more complicated.

Instead, I directly demonstrate the principle importance of different analytical levels by applying widely used standard regression models. Given the nature of the studied farmer groups, I treat the density of the important communication channels inside and outside the community as an indicator of the communication environment in which the individual and group are situated, rather than as exclusive channels of information diffusion, and I examine whether such individual and group characteristics are related to the individual and collective outcomes of interest. This approach allows for the possibility that ideas are generally exchanged and recombined freely in groups whose members actively report learning from others, and that in well-organized groups, farmers may indirectly or unconsciously benefit from other members' ideas, even if they did not recall this member among the selected main information sources.

Because of the context and purpose of this research, i.e., examining the density of internal and external links at the actor and network levels in relation to environmental resource management, I apply conventional statistical approaches rather than using more specialized network methods such as exponential random graph models (ERGMs; Robins et al. 2007). If the aim were to examine the probability of links between households with the same soil management approaches or to examine complex internal network motifs (instead of analyzing the densities of internal and external links), ERGMs and their new extensions (e.g., Wang et al. 2016) would be clearly superior, even if their fit and comparison across a larger number of networks were significantly more complicated. However, such analysis is beyond the scope of this work.

\section{Statistical methods}

After presenting descriptive tables and diagrams of the networks, I provide quantitative estimations. I analyzed the number of links within and outside the farmer groups and the reciprocated links within the groups in relation to organic and chemical fertilizer adoption. The number of intra- and extra-group links signifies the number of advisors outside of the household who can provide agricultural information to the household head (number of outgoing arrows in the network diagrams). The number of reciprocated links is the number of intra-group links for which the reported advisors also mentioned the respondent as the source of information (bidirectional arrows in the network diagrams).

For my purposes, comparable approaches at the household and collective levels need to be used. In the household-level analysis, I used logistic regression to examine what network characteristics distinguish individual households in each soil management category from the rest. The modeling outcome can be zero or one, i.e., a farming household belonging to the particular adoption group or not, respectively. I applied logistic regression with fixed effects to allow for variation in overall fertilizer adoption levels across groups. The model's multi-level structure respects that households are nested within groups and thus are not necessarily statistically independent. At the household level, which has a sufficient number of observations, I first tested every network variable separately and then tested the significant variables in combination. Controls for education and wealth (cultivated land area) were included, and model fit was assessed by its loglikelihood.

The four exclusive soil management strategies can also be treated as four discrete outcomes in a single multinomial logistic model. This approach estimates how likely the independent variables are to belong to a certain category compared with a chosen reference category. As a robustness check, I also applied multinomial regression. The results, which are consistent with the results of the binomial regressions, are reported in Appendix 1.

At the collective level, I analyzed the proportion of farmers from each fertilizer adoption category as a continuous variable by linear regression. As an aggregate measure at the collective level, I used the mean number of intra-group, extra-group, and reciprocated links per member in each farmer group. These measures enable comparison of the network density for networks with different numbers of nodes. Another possibility is to use the popular measure of network density defined as the number of existing links divided by the maximum number of theoretically possible links within the group. In such a calculation, however, the denominator is proportional to the square of the number of members in each farmer group, making comparisons between groups of different sizes problematic (Friedkin 1981). A potential problem with the mean number of links as a comparative measure 
Table 2. Description of farmer groups. Numbers are the means of household values for each farmer group, with within-group standard deviations for the numbers of internal and external links.

\begin{tabular}{|c|c|c|c|c|c|c|c|c|c|c|}
\hline $\begin{array}{l}\text { Farmer } \\
\text { group }\end{array}$ & $\begin{array}{l}\text { Number of } \\
\text { valid } \\
\text { observations }\end{array}$ & $\begin{array}{l}\text { Proportion } \\
\text { of } \\
\text { nonusers }\end{array}$ & $\begin{array}{l}\text { Proportion of } \\
\text { chemical-only } \\
\text { users }\end{array}$ & $\begin{array}{l}\text { Proportion of } \\
\text { organic-only } \\
\text { users }\end{array}$ & $\begin{array}{l}\text { Proportion } \\
\text { of } \\
\text { combined } \\
\text { users }\end{array}$ & $\begin{array}{l}\text { Intra-group } \\
\text { links per } \\
\text { member (SD) }\end{array}$ & $\begin{array}{l}\text { Extra- } \\
\text { group links } \\
\text { per member } \\
\text { (SD) }\end{array}$ & $\begin{array}{l}\text { Reciprocated } \\
\text { links per } \\
\text { member }\end{array}$ & $\begin{array}{l}\text { Area of } \\
\text { cultivated } \\
\text { land (ha) }\end{array}$ & $\begin{array}{c}\text { Finished } \\
\text { primary } \\
\text { school } \\
(1=\text { yes })\end{array}$ \\
\hline 1 & 20 & 0 & 0.05 & 0.05 & 0.90 & $6.40(6.65)$ & $1.15(1.63)$ & 2.60 & 0.82 & 0.95 \\
\hline 2 & 22 & 0.09 & 0.18 & 0.14 & 0.59 & $3.36(1.84)$ & $1.95(1.73)$ & 0.45 & 0.99 & 0.95 \\
\hline 3 & 10 & 0.10 & 0.30 & 0 & 0.60 & $5.40(3.20)$ & $1.90(3.11)$ & 1.40 & 1.20 & 1.00 \\
\hline 4 & 20 & 0.10 & 0.35 & 0.30 & 0.25 & $2.70(2.94)$ & $1.05(1.05)$ & 0.60 & 0.84 & 1.00 \\
\hline 5 & 21 & 0.10 & 0.24 & 0.38 & 0.29 & $2.57(2.25)$ & $1.10(1.04)$ & 0.29 & 0.52 & 0.95 \\
\hline 6 & 18 & 0.06 & 0.22 & 0.06 & 0.67 & $3.44(4.09)$ & $2.06(1.86)$ & 1.22 & 0.99 & 0.94 \\
\hline 7 & 14 & 0 & 0.43 & 0 & 0.57 & $1.43(2.03)$ & $1.79(1.85)$ & 0.14 & 0.91 & 1.00 \\
\hline 8 & 29 & 0.21 & 0.10 & 0.07 & 0.62 & $3.28(2.42)$ & $0.69(1.14)$ & 0.62 & 1.02 & 0.90 \\
\hline 9 & 23 & 0.17 & 0.09 & 0.17 & 0.57 & $4.22(3.72)$ & $1.61(1.59)$ & 0.52 & 0.90 & 0.70 \\
\hline 10 & 17 & 0 & 0.06 & 0.41 & 0.53 & $5.53(4.27)$ & $1.88(2.76)$ & 1.06 & 1.38 & 0.94 \\
\hline 11 & 34 & 0.06 & 0.26 & 0.12 & 0.56 & $3.97(2.87)$ & $1.56(1.83)$ & 0.94 & 1.43 & 0.97 \\
\hline 12 & 24 & 0.08 & 0.21 & 0.13 & 0.58 & $2.21(2.65)$ & $1.50(2.45)$ & 0.17 & 0.83 & 0.92 \\
\hline 13 & 15 & 0.20 & 0.13 & 0.20 & 0.47 & $4.00(4.17)$ & $0.80(0.94)$ & 0.80 & 1.34 & 0.87 \\
\hline 14 & 25 & 0.20 & 0.04 & 0.32 & 0.44 & $4.20(4.50)$ & $1.36(1.44)$ & 0.96 & 0.76 & 0.72 \\
\hline 15 & 7 & 0.14 & 0.29 & 0 & 0.57 & $3.71(1.38)$ & $0.57(0.79)$ & 1.14 & 1.33 & 1.00 \\
\hline 16 & 13 & 0 & 0.15 & 0.31 & 0.54 & $3.46(2.26)$ & $0.92(1.04)$ & 1.08 & 2.02 & 1.00 \\
\hline $\begin{array}{l}\text { Total } \\
\text { mean }\end{array}$ & 19.5 & 0.09 & 0.19 & 0.17 & 0.55 & $3.74(3.08)$ & $1.37(1.64)$ & 0.87 & 1.08 & 0.93 \\
\hline
\end{tabular}

is that the maximum possible number of internal links that a household may have is higher in larger farmer groups. Therefore, I also tested models that control for group size, but group size had no relation with the outcomes of interest, and its inclusion did not change the results qualitatively.

When using averages, it is possible that a single household with many links may significantly raise the average of the whole group. This is a legitimate and common property of real-life networks. Such network hubs greatly increase the connectivity of the whole network and of everyone in it (Barabási and Albert 1999). All members who are connected to this popular household head are connected with each other by a maximum of only two steps. Thus, it is correct to assume that a group is highly connected if it includes active individuals who connect with everyone else.

Because there are only 16 observations at the group level, the number of explanatory variables that can be input simultaneously into the models is extremely limited. When I included more than one explanatory network variable in the model at the collective level, no predictor remained significant. Therefore, all network measures were tested against the adoption outcomes separately. Analogous to the household-level analysis, I controlled for the mean cultivated area of the farmers in the group and the proportion of households with educated members. The fit of the collective-level models was assessed using the $R^{2}$, which quantifies the proportion of the variation of the outcome variable explained by the explanatory variables. All analyses were carried out in Stata 11 (StataCorp 2009).

\section{RESULTS AND DISCUSSION}

\section{Descriptive quantitative results}

For the analysis of network measures at the household level, there is neither complementarity nor substitution between the intra- and extra-group links; they are statistically independent $(R=$ $-0.06, P=0.3$; Table 1$)$. The reciprocated links are a subset of the internal links, and thus, their count is correlated $(R=0.66, P$ $<0.01)$.

Urea is the most heavily used chemical fertilizer, used by 141 farmers. For 75 farmers, the main chemical fertilizer is NPK. Dried animal manure is the main component of organic fertilizers for 170 farmers, and fresh animal manure is the main component for 26 farmers. However, the usage of organic fertilizers is not correlated with ownership of any type of animals within the household.

There is no correlation between the number of internal and external links at the collective level $(R=0.08, P=0.8$; Table 2). Both farmer groups and individual household heads can be externally oriented, internally oriented, have an abundance of both types of links, or have neither links. The average number of internal links per member and the standard deviation of the number of links are strongly correlated $(R=0.71, P<0.01)$, suggesting that denser groups tend also to be more centralized; in other words, more interconnected groups tend to be groups with a smaller number of active members facilitating the connectivity of the group. Similarly, communities with good external linkages tend to have several members who work as a bridge between the group and the external world (degree and standard deviation; $R=0.76, P<0.01$ ).

For illustration, consider two contrasting examples of farmer group networks (Fig. 2). Members of farmer group 1 have the greatest number of internal links. Combining organic and chemical fertilizers is the standard in this group; $90 \%$ of the members in this cohesive group use this practice. Farmer group 7 is a contrasting case. This group has the smallest number of internal links per member and the highest proportion of farmers 
Table 3. Household-level logit model estimation with fixed effects at the group level. The outcome variable indicates the likelihood of belonging to the fertilizer adoption category specified above each set of models.

\begin{tabular}{|c|c|c|c|c|c|c|c|c|c|}
\hline \multirow{2}{*}{$\begin{array}{l}\text { Fertilizer use } \\
\text { Model }\end{array}$} & \multicolumn{4}{|c|}{ Organic-only } & & \multicolumn{4}{|c|}{ Combined users } \\
\hline & 1 & 2 & 3 & 4 & & 1 & 2 & 3 & 4 \\
\hline Internal links & -0.014 & & & & & 0.138 & & & \\
\hline External links & & 0.115 & & & & & 0.008 & & \\
\hline Reciprocated links & & & 0.084 & & & & & 0.156 & \\
\hline Finished primary school $(1=$ yes $)$ & $1.337 \dagger$ & 1.291 & $1.363 \dagger$ & $1.335 \dagger$ & & 0.079 & 0.074 & -0.009 & 0.077 \\
\hline Area of cultivated land (ha) & -0.227 & -0.234 & -0.216 & -0.224 & & 0.203 & 0.206 & 0.199 & 0.207 \\
\hline Constant & $-0.227 * *$ & $-2.208^{* *}$ & $-2.731 * *$ & $-2.770 * *$ & & -0.044 & -0.106 & -0.149 & -0.098 \\
\hline Number of observations & 308 & 308 & 308 & 308 & & 308 & 308 & 308 & 308 \\
\hline Number of groups & 16 & 16 & 16 & 16 & & 16 & 16 & 16 & 16 \\
\hline Log likelihood & -136.15 & -135.4 & -136.0 & -136.2 & & -209.7 & -209.7 & -208.4 & -209.7 \\
\hline Variance at group level & 0.748 & 0.764 & 0.737 & 0.746 & & 0.420 & 0.406 & 0.341 & 0.407 \\
\hline Likelihood-ratio test of $\rho=0$ & 0.004 & 0.004 & 0.005 & 0.005 & & 0.040 & 0.045 & 0.111 & 0.045 \\
\hline Fertilizer use & \multicolumn{5}{|c|}{ Nonusers } & \multicolumn{4}{|c|}{ Chemical-only } \\
\hline Model & 1 & 2 & 3 & 4 & 5 & 1 & 2 & 3 & 4 \\
\hline Internal links & $0.130^{* *}$ & & & & $0.112 *$ & -0.079 & & & \\
\hline External links & & $-0.433^{*}$ & & & $-0.397 *$ & & -0.017 & & \\
\hline Reciprocated links & & & 0.122 & & & & & $-0.368^{*}$ & \\
\hline Finished primary school $(1=$ yes $)$ & $-0.156^{* *}$ & $-1.412^{* *}$ & $-1.540 * *$ & $-1.478 * *$ & $-1.459 * *$ & 0.515 & 0.449 & 0.659 & 0.454 \\
\hline Area of cultivated land (ha) & $-0.862 *$ & $-0.758 \dagger$ & $-0.818^{*}$ & $-0.782 *$ & $-0.854 *$ & 0.117 & 0.139 & 0.182 & 0.141 \\
\hline Constant & -0.784 & 0.059 & -0.312 & -0.285 & -0.398 & $-1.835^{* *}$ & $-2.103^{* *}$ & $-2.025^{* *}$ & $-2.084^{* *}$ \\
\hline Number of observations & 308 & 308 & 308 & 308 & 308 & 308 & 308 & 308 & 308 \\
\hline Number of groups & 16 & 16 & 16 & 16 & 16 & 16 & 16 & 16 & 16 \\
\hline Log likelihood & -87.4 & -87.2 & -89.9 & -90.8 & -84.2 & -144.8 & -146.2 & -143.0 & 146.2 \\
\hline Variance at group level & 0.192 & 0.001 & 0.041 & 0.002 & 0.002 & 0.277 & 0.382 & 0.270 & 0.383 \\
\hline Likelihood-ratio test of $\rho=0$ & 0.436 & 0.499 & 0.499 & 0.499 & 0.499 & 0.296 & 0.172 & 0.305 & 0.170 \\
\hline
\end{tabular}

${ }^{*} P<0.05,{ }^{* *} P<0.01, \dagger P<0.1$.

Fig. 2. Network diagrams showing the information-sharing networks in two farmer groups with contrasting soil management practices: farmer group 1 (top) and farmer group 7 (bottom). Black nodes and links $=$ farmer group members and intra-group links; light gray nodes and links = external information sources and extra-group links. Arrows point from respondent to his/her agricultural information sources.

Reciprocal links have arrowheads on both ends. Figure created using Ucinet (Borgatti et al. 2002).

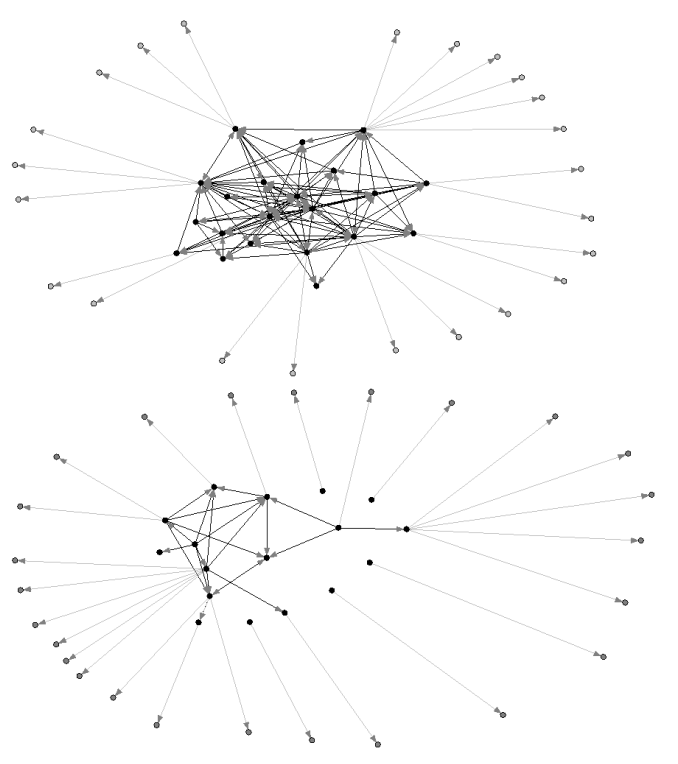

who use only chemical fertilizers. Statistical analyses quantitatively examined whether there are any general trends between network structure and soil management practices in different groups.

\section{Household-level quantitative estimation}

Social networks of farmers who do not use any fertilizers are centered on their farmer groups (nonusers model 5, the bestfitting household-level model for this group; Table 3). Nonusers have more links within and fewer links outside of their groups compared with other farmers. Non-network factors also matter. Nonuser households cultivate smaller areas than others and are more likely to be composed of members who did not finish primary school (Fig. 3). Nonusers' local orientation, lack of connections with external society, lower education, and lower wealth match the findings from numerous previous actor-level innovation diffusion studies (see Rogers 2003 for a comprehensive review). It should be noted that the independent variables, i.e., education, cultivated land, and the number of internal and external links, are uncorrelated. Primary education and the amount of cultivated land do not predict the number of links inside and outside of the group (all $R<0.1, P>0.1$; Fig. 3)

The distinguishing characteristic of organic-only households is their higher rate of education (Table 3, Fig. 3). Beyond education, the inclusion of other network measures does not further improve the fit of the organic-only models.

Although heads of chemical-only households do not report fewer information sources than other farmers, they have a relative lack of reciprocal relationships with others, which are a prerequisite 
for mutual information sharing and collective experimentation with new techniques (best-fitting chemical-only model 3; Table 3, Fig. 3). Few chemical-only farmers' network partners consider chemical-only farmers to be important information sources.

Fig. 3. Summary of household-level model estimation results. Each box displays household characteristics that are positively or negatively associated with each soil management strategy.

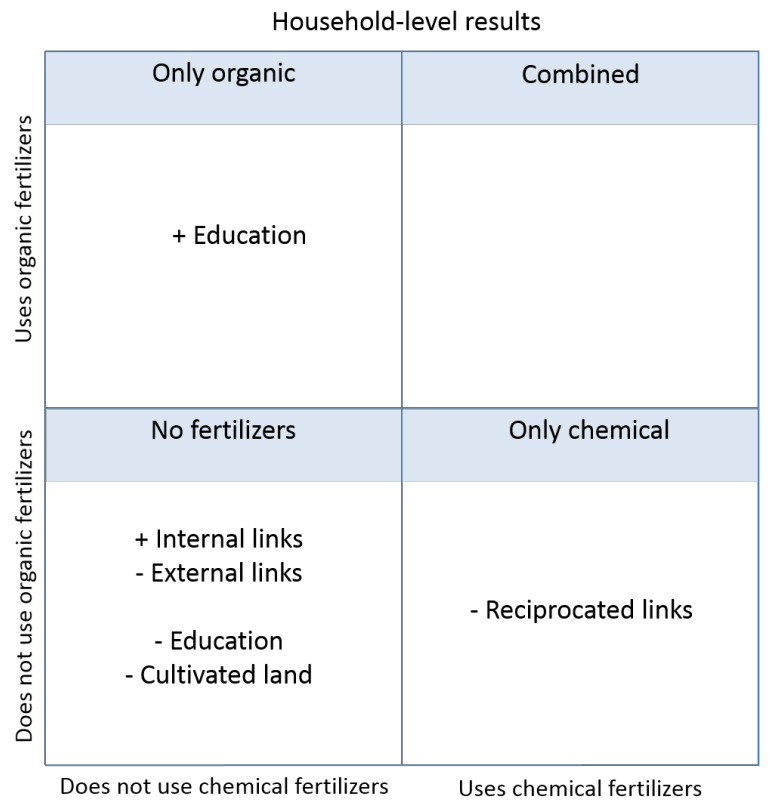

Finally, none of the introduced explanatory variables predict the propensity of individual households to combine organic and chemical fertilizers productively (nonsignificant outcomes of combined users models; Table 3, Fig. 3).

The test of $\rho$ (Table 3 ) suggests that the inclusion of fixed effects was not necessary in the nonusers and chemical-only models. For these models, simple logistic regression would have produced the same results. In contrast, the test values are low for the organiconly and combined users' models, which means that the inclusion of fixed effects is recommended to account for the variation in overall fertilizer adoption levels among groups.

I use the nonusers model 5 (Table 3 ) to illustrate how the coefficients translate into farmers' probabilities of belonging to the respective soil management categories. One additional internal link increases the odds of not using any kind of fertilizer by $12 \%\left(e^{0.112}=1.12\right)$; each additional external link decreases the odds by $33 \%\left(e^{-0.397}=0.67\right)$; having someone in the household who has finished at least primary school decreases the odds by $77 \%\left(e^{-1.459}=0.23\right)$; and every additional hectare of cultivated land decreases the odds of not using any fertilizers by $57 \%$ $\left(e^{-0.854}=0.43\right)$. Formal education appears to be very important at the household level. The relevance of school education in this model is quantitatively equivalent to approximately three interpersonal sources of information outside of the group ( $e$ $\left.{ }^{[-0.397 \times 3]}=0.3\right)$. This household-level statistical association between organic fertilization and education also suggests that organic agriculture is progressive in this context, as opposed to in some less-developed countries, where organic agriculture is the default traditional approach and the application of chemical fertilizers is considered innovative. This interpretation is consistent with the information obtained in qualitative interviews. In contrast, the low popularity of chemical-only farmers as advisors signifies their lack of opinion leadership in agricultural matters and a lack of general interest in their production methods.

Multinomial regression produced results consistent with the binomial regressions. Combined users, the largest adoption category (which had no significant predictors in the binomial analysis), was the reference category in the multinomial regression. The results show that nonusers are distinguishable from combined users by more internal links, fewer external links, lower education, and a smaller area of cultivated land (Appendix 1). Chemical-only farmers have fewer reciprocated links than do combined users. The only difference between the results of the multinomial model and those of the logistic models is that organic-only farmers are more educated than the rest of the sample in the binomial model but are not significantly more educated than combined users in the multinomial model. Thus, organic-only farmers' higher rates of education distinguish them specifically from the two groups of farmers who do not use any organic fertilizers (nonusers and chemical-only farmers).

\section{Group-level quantitative estimation}

The estimation results differ in some aspects when conducted at the farmer group level (Table 4, Fig. 4). Groups with a high proportion of nonusers are similar to nonuser households in two repects: they have a high proportion of uneducated households and few external links. Interestingly, farmer groups with a high proportion of households who combine chemical and organic fertilizers have dense webs of internal links, particularly reciprocal links, suggesting the importance of strong mutual ties for sustainable productivity enhancement. This pattern is in contrast to results from the household-level analysis in which localized links were characteristic of nonuser households. At the collective level, an additional internal link per group member predicts a $6 \%$ increase in the proportion of combined users in the farmer group (15\% for a reciprocated link).

Groups with a high proportion of farmers who try to enhance their productivity only by using chemical fertilizers have fewer dense connections and fewer internal reciprocated links. In addition to an overall lack of internal connections, a lack of reciprocal relationships at the collective level suggests hierarchical structures among advisors and advisees in which information and influence flows mainly in one direction from the former to the latter, with a lack of feedback. The strength of the relationship for the chemical-only models $\left(R^{2}\right.$, Table 4$)$ suggest that these very simple models explain almost $70 \%$ of intergroup variation in the proportion of chemical-only users. The statistically indicated importance of reciprocity corresponds with earlier theoretical propositions in the environmental management literature (Plummer and Fennell 2007). In contrast to the household-level results, farmer groups with a high proportion of chemical-only users have a high proportion of educated households. 
Table 4. Collective-level ordinary least squares estimation. The outcome variable indicates the proportion of farmers from each fertilizer adoption category in the farmer group.

\begin{tabular}{|c|c|c|c|c|c|c|c|c|}
\hline \multirow[t]{2}{*}{ Fertilizer use } & \multicolumn{4}{|c|}{ Organic-only } & \multicolumn{4}{|c|}{ Combined users } \\
\hline & 1 & 2 & 3 & 4 & 1 & 2 & 3 & 4 \\
\hline Internal links & 0.007 & & & $0.059 \dagger$ & & & & \\
\hline External links & & -0.025 & & & 0.071 & & & \\
\hline Reciprocated links & & & -0.050 & & & $0.154^{*}$ & & \\
\hline $\begin{array}{l}\text { Finished primary school }(1= \\
\text { yes })\end{array}$ & -0.434 & -0.407 & -0.390 & -0.411 & 0.213 & 0.001 & -0.054 & 0.013 \\
\hline Area of cultivated land (ha) & 0.052 & 0.039 & 0.061 & 0.045 & -0.006 & 0.071 & 0.005 & 0.055 \\
\hline Constant & 0.536 & 0.534 & 0.504 & 0.498 & -0.136 & 0.372 & 0.455 & 0.475 \\
\hline Number of observations & 16 & 16 & 16 & 16 & 16 & 16 & 16 & 16 \\
\hline$R^{2}$ & 0.073 & 0.078 & 0.113 & 0.070 & 0.248 & 0.071 & 0.390 & 0.018 \\
\hline Fertilizer use & \multicolumn{4}{|c|}{ Nonusers } & \multicolumn{4}{|c|}{ Chemical-only } \\
\hline Model & 1 & 2 & 3 & 4 & 1 & 2 & 3 & 4 \\
\hline Internal links & -0.010 & & & $-0.042 *$ & & & & \\
\hline External links & & $-0.038 *$ & & & 0.022 & & & \\
\hline Reciprocated links & & & -0.023 & & & $-0.081^{*}$ & & \\
\hline $\begin{array}{l}\text { Finished primary school }(1= \\
\text { yes })\end{array}$ & $-0.512^{*}$ & $-0.467^{*}$ & $-0.469^{*}$ & $-0.479^{*}$ & $0.733^{* *}$ & $0.873^{* *}$ & $0.912 * *$ & $0.877^{* *}$ \\
\hline Area of cultivated land (ha) & -0.003 & -0.028 & -0.005 & -0.013 & -0.043 & -0.082 & -0.061 & -0.087 \\
\hline Constant & $0.606^{* *}$ & $0.649^{*}$ & $0.554^{*}$ & $0.551^{* *}$ & -0.279 & $-0.555^{*}$ & $-0.513^{*}$ & $-0.524^{*}$ \\
\hline Number of observations & 16 & 16 & 16 & 16 & 16 & 16 & 16 & 16 \\
\hline$R^{2}$ & 0.419 & 0.583 & 0.428 & 0.395 & 0.674 & 0.481 & 0.646 & 0.473 \\
\hline
\end{tabular}

Fig. 4. Summary of collective-level model estimation results. Each box displays farmer group characteristics that are positively or negatively associated with the prevalence of farmers from each soil management category.

Collective-level results

\begin{tabular}{|c|c|}
\hline $\begin{array}{c}\text { High proportion of } \\
\text { only organic users }\end{array}$ & $\begin{array}{c}\text { High proportion of } \\
\text { combined users }\end{array}$ \\
& $\begin{array}{c}\text { + Internal links } \\
+ \text { Reciprocated links }\end{array}$ \\
& \\
\hline High proportion of & High proportion of \\
no fertilizer users & only chemical users \\
\hline & \\
- External links & - Internal links \\
- Education & Reciprocated links \\
& + Education \\
\hline
\end{tabular}

Although distinct characteristics distinguish chemical-fertilizer farmer groups from other groups, organic fertilizer groups are diverse. None of the tested group-level attributes reliably predicts the proportion of purely organic farmers in a farmer group. Finally, the average cultivated area is not significant in any of the group-level models. This average measure may not be a meaningful aggregate conceptualization of group-level affluence.

Findings from qualitative interviews

Whereas chemical fertilizers have been used in the region for decades, organic fertilizers have become widely popular only within the last several years. Until relatively recently, the addition of organic nutrients was nonsystematic. Interviews with actors at different levels of the local agricultural system provide a complementary perspective on the drivers of this change.

According to representatives of the Forestry and Crop Estate Service Department of Tanggamus district, the department's current two highest priorities are the promotion of organic fertilizers and the improvement of farmer connections to markets through infrastructure development. The main reason for the promotion of organic fertilizers is to increase the demand for Indonesian agricultural products in global markets. Officials have stated that this policy orientation is partially a response to requests from global coffee traders. The most important triggering event was reportedly an incident in 2012 in which $300,000 \mathrm{~kg}$ of coffee from the surveyed districts was returned from Japan after laboratory testing uncovered chemical residuals above permitted levels.

The local government relies on its links through extension agents to official farming group leaders to promote the recommended policies at the community level. The Forestry and Crop Estate 
Service Department has obtained funding from the central government for organic fertilizer promotion events such as the distribution of free, high-quality, composite organic fertilizers to farming group leaders for demonstration purposes. Farmer groups that are judged as well managed and progressive by extension agents may receive higher subsidies. Fragmented groups that cannot promote the recommended practices receive fewer benefits from the government.

Farmers who have begun systematic use of organic fertilizers typically learned the technique via their links with extension agents, traders and importers, relatives in other villages, or community members who learned it from external sources. However, farmers adapt the promoted methods to their needs and local conditions based on their experience and that of their peers. The informants had experimented with different types of leaves and plant residuals, goat urine, and water in different proportions for optimal results. In some communities, fertilizer had been allowed to ferment for periods ranging from none or several days to several months, and residents shared their experiences with one another. Furthermore, although goats (which are common in every village) produce manure daily, manure application is less frequent. In some communities, farmers use their networks to share currently unused manure with those who need it at a particular moment.

Farmers who have begun to use organic fertilizers provided the following explanations for their decision. First, they expressed concern regarding the perceived declining fertility of their fields. One farmer likened the soil on his field to a sick patient and chemical fertilizers to the increasing amounts of drugs that it requires for survival. The informants claimed that they could see immediate positive effects from organic fertilizers. Two farmers in farmer group 1 reported that their soil became softer and darker, worms returned, and their coffee plants became visibly more resilient to extended periods of drought. Second, the informants explained that in recent years, a global-level coffee trader (Nestlé) became a major stakeholder in the region. Currently, most farmers sell coffee beans either directly or indirectly to this exporter, which has recommended that the farmers partially substitute chemical fertilizers with organic ones. The exporter also visits the producers' plots to discourage them from applying excessive amounts of chemical inputs. Third, some farmers are increasingly turning toward organic fertilizers to decrease their expenditures, and subsidies for chemical fertilizers are being withdrawn.

Chemical fertilizer users who have started using organic fertilizers typically have not stopped using chemical fertilizers completely. These farmers feel that eliminating chemical nutrient inputs completely would require excessive effort in the application of high volumes of organic fertilizers, which is not justified by the low perceived premium currently paid for fully organic coffee beans. One heavy fertilizer user who used to apply chemical fertilizer every week is now experimenting with using chemical fertilizer only biweekly, with with organic fertilizers in alternate weeks; another farmer applies a layer of organic fertilizer below the chemical fertilizer in an effort to regulate the release of nutrients and improve their absorption; a third farmer applies an organic fertilizer cover only at the beginning and end of the rainy season, when he believes nutrients tend to be flushed away.
The typical organic-only farmer appears to be an educated individual who was selected by external experts to learn about organic soil enrichment in recent efforts to improve agricultural practices in less-educated farmer groups in which productivityenhancing techniques were uncommon. This practice would explain why educated households are more likely to use only organic fertilizers, but farmer groups with a higher proportion of educated households tend to have a higher proportion of sole chemical fertilizer users. This result provides empirical support for Liu et al.'s (2007) suggestion that relative education may, in some contexts, be more consequential than absolute education achievements.

Importantly, no one, even when explicitly asked, considered the effects on the environment outside of their plot, be it local rivers or the global climate, in their choice of fertilizers. Even the sole organic fertilizer users expressed no concern for the environment outside of the condition of the soil on their fields. Similarly, the local government representatives did not consider environmental impacts outside of the farmers' plots as a reason for promoting the transition to organic fertilizers.

The qualitative descriptions help to shed light on the divergent quantitative results regarding the role of networks at the household and collective levels. Whereas household heads whose relationships focus on their farmer groups are significantly less productivity driven in their choice of farming techniques, the opposite is true at the collective level. Nonhierarchical groups with high levels of reciprocal internal connectedness are characterized by high adoption rates of a productivity-enhancing combination of chemical and organic fertilizers. It appears that the intra-group orientation of some individuals, while possibly limiting their own direct access to new information outside the group, has productive externalities for the collective by binding the group together and creating a place in which productive approaches can be shared. By contrast, individuals who seek information from higher-level organizations and other communities can help their own groups by bringing in new knowledge, while the localites whose lives are rooted inside the neighborhood can contribute to the community by working as a binder that increases internal cohesion and creates a cooperative space for cosmopolitan productivity seekers to share their experiences. In particular, nonhierarchical, mutually reciprocated information- and resource-exchange relationships in a community seem to enable experimentation and information sharing regarding more sustainable and productive soil management practices. This outcome corresponds with findings from business management research showing that teams with high levels of reciprocated relationships perform better (Krackhardt and Hanson 1993).

\section{CONCLUSIONS AND IMPLICATIONS}

By combining actor-level and network-level analyses, my results provide empirical support for theories that communities of resource users need both internal and external links for sustainable environmental management. The well-documented disadvantage of individuals with inadequate links outside of their communities was also confirmed at the collective level: whole villages may depend on uninformed techniques when their links to higher-level institutions and other communities are lacking. The collective-level analysis also uncovered the importance of 
internal integration, which could not be observed at the household level. At the household level, the effect of relationships with fellow group members may seem negative because locally rooted individuals tend to be more hesitant to adopt progressive techniques. However, at the collective level, reciprocal intra-group relationships seem to be a prerequisite for the widespread adoption of recommended practices. Natural resource management with the involvement of local user communities has become increasingly popular (Kapoor 2001, Pretty 2003, Plummer and Fitzgibbon 2004, Pretty and Smith 2004, Carlsson and Berkes 2005, Fraser et al. 2006, Plummer and Fennell 2007, Berkes 2009, Dyer et al. 2014), and community-based development has become a requirement by international development agencies in many low-income countries (Cooke and Kothari 2001, Hickey and Mohan 2004, Matous 2013). However, policy makers should not offload all their responsibilities for environmental protection to communities that are, in fact, simply groups of unrelated people living in the same place, formally bound together by a request from external governmental agents. This recommendation also applies to the farmer groups in this study. Not all communities in community-based natural resource management are created equal, and my research demonstrates the consequences of this fact. When groups of people through which governmental interventions are channeled and policies are administered do not have sufficient internal and external connections, their outcomes may be inadequate. Moreover, caution is necessary because neighborhood relations tend to be weakened further by the forces of economic development. Research suggests that the modernization of rural areas enables the creation of geographically distant intercommunal links while simultaneously decreasing social contact within local settlements (Matous et al. 2013a, 2015). From the viewpoint of natural resource management, policy makers must search for development strategies that do not negatively affect the existing internal social fabric of local villages.

Most importantly, my findings highlight the necessity of explicitly considering multiple levels of analysis of environmental management strategies. Statements regarding which types of networks are conducive to desired environmental outcomes may be misleading without specifying the level of the effect. It has been recommended that theoretical knowledge be accumulated by focusing on individual processes from which final outcomes are composed (see review by Rodela 2011). The individualistic approach is less data demanding than analysis across whole networks and provides important insights into individual differences within communities. However, this approach also has drawbacks. The simple aggregation of household-level results may lead to an inaccurate understanding of changing environmental behaviors at the meso and macro scales. The consequences of each person's network aggregate at higher levels in nontrivial ways, and findings based solely on household-level studies may lead to misguided policies for the sustainable development of communities, regions, and whole ecosystems. Thus, even if most actor-level studies show that certain types of personal networks are conducive to individuals' proenvironmental behavior, it is not clear whether promoting such networks would lead to optimal aggregate environmental consequences at larger scales. The collective-level analysis performed here illustrates that even the commonly found relevance of education may not translate to pro-environmental behavior in a straightforward way on a larger scale.

Although economic globalization pressures are typically associated with damage to local ecosystems (Brondizio et al. 2009), my results show that economic development and conservation goals may be integrated in some cases. Increasing global demand for produce that is perceived to be safe and healthy (Freyer et al. 2014), mediated through the links connecting international coffee traders to local governments, community organizations, and local farmers, resulted in a change in the practices farmers use on their plots, which may in turn have environmental effects at the global level. In this case, the external relationships of community-based organizations to external higher institutions delivered the necessary stimulus and information to remote villages, and dense networks of reciprocal links within some of these organizations enabled mutual exchanges of experience and promoted implementation of the new technique. The adoption of the recommended fertilizer practices was driven by the producers' concern for the health of soil on their own property and global consumers' demand for a certain type of produce. Although Indonesian watersheds and the global nitrogen cycle are most likely not the reason consumers prefer coffee without excessive chemical residuals, consumers' purchasing decisions may make a difference. In the future, the conscience of the world's growing middle class in increasingly globalized markets could be further directed toward certified products that indirectly compensate small-holders in developing countries through price premiums for using more demanding techniques that preserve local and global ecosystems.

Whereas environmental studies at the individual and the societal levels are relatively common, the meso level deserves more attention (Bergström and Dekker 2014). Forms of organization can vary radically from group to group, and it is important to understand these structures before trying to intervene from outside. Internal and external linkages and their degree of reciprocation can empirically reflect important aspects of the social structure of each community-based organization. If possible, link direction and connections reaching outside the communities in focus should not be ignored in empirical socialenvironmental network studies. Furthermore, it is problematic to analyze complex multi-level nested systems according to traditional econometric methods or common social science statistical tools alone. However, new tools of network science for dealing with multi-level networks are becoming increasingly available (Wang et al. 2013, 2016). The application of such tools will help in future to identify determinants of success in systems that are not self-contained and will enable improved integration of social and ecological sciences. Inevitably, statistical models of whole networks explicitly model only links inside the network boundary. A feasible step forward in such modeling frameworks would be to include the number of links reaching outside the boundary as an actor covariate. Furthermore, datasets with a larger number of networks from more regions are needed to explain fully the mechanisms proposed here and to control for numerous other possibly confounding effects. Finally, it is desirable to include a temporal dimension in future studies to better explore the dynamics of multilevel social-environmental problems. To this end, longitudinal network data gathering is in progress. 
Responses to this article can be read online at:

http://www.ecologyandsociety.org/issues/responses. $\mathrm{php/7816}$

\section{Acknowledgments:}

This study was financially supported by the Ministry of Education, Culture, Sports, Science and Technology, Japan. I thank Ayu Pratiwi for supervising the data gathering.

\section{LITERATURE CITED}

Abrahamse, W., and L. Steg. 2013. Social influence approaches to encourage resource conservation: a meta-analysis. Global Environmental Change 23(6):1773-1785. http://dx.doi.org/10.1016/ j.gloenvcha.2013.07.029

Barabási, A.-L., and R. Albert. 1999. Emergence of scaling in random networks. Science 286(5439):509-512. http://dx.doi. org/10.1126/science.286.5439.509

Bergsten, A., D. Galafassi, and Ö. Bodin. 2014. The problem of spatial fit in social-ecological systems: detecting mismatches between ecological connectivity and land management in an urban region. Ecology and Society 19(4): 6. http://dx.doi. org/10.5751/es-06931-190406

Bergström, J., and S. W. A. Dekker. 2014. Bridging the macro and the micro by considering the meso: reflections on the fractal nature of resilience. Ecology and Society 19(4): 22. http://dx.doi. org/10.5751/es-06956-190422

Berkes, F. 2009. Evolution of co-management: role of knowledge generation, bridging organizations and social learning. Journal of Environmental Management 90(5):1692-1702. http://dx.doi. org/10.1016/j.jenvman.2008.12.001

Bodin, Ö., and B. I. Crona. 2009. The role of social networks in natural resource governance: What relational patterns make a difference? Global Environmental Change 19(3):366-374. http:// dx.doi.org/10.1016/j.gloenvcha.2009.05.002

Bodin, Ö., and C. Prell. 2011. Social network analysis in natural resource governance: summary and outlook. Pages 347-373 in Ö. Bodin and C. Prell, editors. Social networks and natural resource management: uncovering the social fabric of environmental governance. Cambridge University Press, Cambridge, UK. http:// dx.doi.org/10.1017/cbo9780511894985.015

Bodin, Ö., and M. Tengö. 2012. Disentangling intangible socialecological systems. Global Environmental Change 22(2):430-439. http://dx.doi.org/10.1016/j.gloenvcha.2012.01.005

Borgatti, S. P., M. G. Everett, and L. C. Freeman. 2002. Ucinet for Windows: software for social network analysis. Analytic Technologies, Harvard, Massachusetts, USA.

Breman, H., J. J. R. Groot, and H. van Keulen. 2001. Resource limitations in Sahelian agriculture. Global Environmental Change 11(1):59-68. http://dx.doi.org/10.1016/s0959-3780(00)00045-5

Brockhaus, M., and M. Di Gregorio. 2014. National REDD+ policy networks: from cooperation to conflict. Ecology and Society 19(4): 14. http://dx.doi.org/10.5751/es-06643-190414
Brondizio, E. S., E. Ostrom, and O. R. Young. 2009. Connectivity and the governance of multilevel social-ecological systems: the role of social capital. Annual Review of Environment and Resources 34:253-278. http://dx.doi.org/10.1146/annurev.environ.020708.100707

Brummel, R. F., K. C. Nelson, and P. J. Jakes. 2012. Burning through organizational boundaries? Examining inter-organizational communication networks in policy-mandated collaborative bushfire planning groups. Global Environmental Change 22 (2):516-528. http://dx.doi.org/10.1016/j.gloenvcha.2011.12.004

Burt, R. S. 1995. Structural holes: the social structure of competition. Harvard University Press, Cambridge, Massachusetts, USA.

Carien De Villiers, A., K. J. Esler, and A. T. Knight. 2014. Social processes promoting the adaptive capacity of rangeland managers to achieve resilience in the Karoo, South Africa. Journal of Environmental Management 146:276-283. http://dx.doi.org/10.1016/ j.jenvman.2014.08.005

Carlsson, L., and F. Berkes. 2005. Co-management: concepts and methodological implications. Journal of Environmental Management 75(1):65-76. http://dx.doi.org/10.1016/j.jenvman.2004.11.008

Cash, D. W., W. N. Adger, F. Berkes, P. Garden, L. Lebel, P. Olsson, L. Pritchard, and O. Young. 2006. Scale and cross-scale dynamics: governance and information in a multilevel world. Ecology and Society 11(2): 8. [online] URL: http://www.ecologyandsociety. org/vol11/iss2/art8/.

Cassman, K. G. 1999. Ecological intensification of cereal production systems: yield potential, soil quality, and precision agriculture. Proceedings of the National Academy of Sciences 96 (11):5952-5959. http://dx.doi.org/10.1073/pnas.96.11.5952

Cheong, S.-M. 2012. Community adaptation to the Hebei-Spirit oil spill. Ecology and Society 17(3): 26. http://dx.doi.org/10.5751/ es-05079-170326

Coleman, J. S. 1988. Social capital in the creation of human capital. American Journal of Sociology 94:S95-S120. [online] URL: http://www.jstor.org/stable/2780243.

Coleman, J. S. 1990. Foundations of social theory. Harvard University Press, Cambridge, Massachusetts, USA.

Colten, C. E., J. Hay, and A. Giancarlo. 2012. Community resilience and oil spills in coastal Louisiana. Ecology and Society 17(3): 5. http://dx.doi.org/10.5751/es-05047-170305

Conley, T. G., and C. R. Udry. 2010. Learning about a new technology: pineapple in Ghana. American Economic Review 100 (1):35-69. http://dx.doi.org/10.1257/aer.100.1.35

Cooke, B., and U. Kothari, editors. 2001. Participation: the new tyranny? Zed Books, London, UK.

Cordell, D., J.-O. Drangert, and S. White. 2009. The story of phosphorus: global food security and food for thought. Global Environmental Change 19(2):292-305. http://dx.doi.org/10.1016/ j.gloenvcha.2008.10.009

Crona, B., and Ö. Bodin. 2010. Power asymmetries in small-scale fisheries: a barrier to governance transformability? Ecology and Society 15(4): 32. [online] URL: http://www.ecologyandsociety. org/vol15/iss4/art32/. 
Deehr, R. A., J. J. Luczkovich, K. J. Hart, L. M. Clough, B. J. Johnson, and J. C. Johnson. 2014. Using stable isotope analysis to validate effective trophic levels from Ecopath models of areas closed and open to shrimp trawling in Core Sound, NC, USA. Ecological Modelling 282:1-17. http://dx.doi.org/10.1016/j. ecolmodel.2014.03.005

Dell'Apa, A., J. C. Johnson, D. G. Kimmel, and R. A. Rulifson. 2013. The international trade and fishery management of spiny dogfish: a social network approach. Ocean and Coastal Management 80:65-72. http://dx.doi.org/10.1016/j. ocecoaman.2013.04.007

Dietz, T., E. Ostrom, and P. C. Stern. 2003. The struggle to govern the commons. Science 302(5652):1907-1912. http://dx.doi. org/10.1126/science.1091015

Dyer, J., L. C. Stringer, A. J. Dougill, J. Leventon, M. Nshimbi, F. Chama, A. Kafwifwi, J. I. Muledi, J.-M. K. Kaumbu, M. Falcao, S. Muhorro, F. Munyemba, G. M. Kalaba, and S. Syampungani. 2014. Assessing participatory practices in community-based natural resource management: experiences in community engagement from southern Africa. Journal of Environmental Management 137:137-145. http://dx.doi.org/10.1016/ j.jenvman.2013.11.057

Engle, N. L., and M. C. Lemos. 2010. Unpacking governance: building adaptive capacity to climate change of river basins in Brazil. Global Environmental Change 20(1):4-13. http://dx.doi. org/10.1016/j.gloenvcha.2009.07.001

Erickson, B. H. 2001. Good networks and good jobs: the value of social capital to employers and employees. Pages 127-158 in N. Lin, K. Cook, and R. S. Burt, editors. Social capital: theory and research. Aldine de Gruyter, New York, New York, USA.

FAO [Food and Agriculture Organization]. 2005. Fertilizer use by crop in Indonesia. FAO, Rome, Italy. [online] URL: http://www. fao.org/docrep/008/y7063e/y7063e00.htm.

Fraser, E. D. G., A. J. Dougill, W. E. Mabee, M. Reed, and P. McAlpine. 2006. Bottom up and top down: analysis of participatory processes for sustainability indicator identification as a pathway to community empowerment and sustainable environmental management. Journal of Environmental Management 78(2):114-127. http://dx.doi.org/10.1016/j.jenvman.2005.04.009

Freyer, B., J. Bingen, and R. Paxton. 2014. Can multicriteria assessment tools help build trust into organic products? Ecology and Society 19(4): 5. http://dx.doi.org/10.5751/ES-06793-190405

Friedkin, N. E. 1981. The development of structure in random networks: an analysis of the effects of increasing network density on five measures of structure. Social Networks 3(1):41-52. http:// dx.doi.org/10.1016/0378-8733(81)90004-6

Gee, J. P. 2013. The anti-education era: creating smarter students through digital learning. MacMillan, New York, New York, USA.

Gibson, C. C., E. Ostrom, and T. K. Ahn. 2000. The concept of scale and the human dimensions of global change: a survey. Ecological Economics 32(2):217-239. http://dx.doi.org/10.1016/ $\underline{\mathrm{s} 0921-8009(99) 00092-0}$

Granovetter, M. S. 1973. The strength of weak ties. American Journal of Sociology 78(6):1360-1380. [online] URL: http://www. istor.org/stable/2776392.
Hansen, M. C., S. V. Stehman, P. V. Potapov, B. Arunarwati, F. Stolle, and K. Pittman. 2009. Quantifying changes in the rates of forest clearing in Indonesia from 1990 to 2005 using remotely sensed data sets. Environmental Research Letters 4(3): 034001. http://dx.doi.org/10.1088/1748-9326/4/3/034001

Hickey, S., and G. Mohan, editors. 2004. Participation: from tyranny to transformation? Exploring new approaches to participation in developmen. Zed Books, London, UK.

Hoang, L. A., J.-C. Castella, and P. Novosad. 2006. Social networks and information access: implications for agricultural extension in a rice farming community in northern Vietnam. Agriculture and Human Values 23(4):513-527. http://dx.doi. org/10.1007/s10460-006-9013-5

Hufnagl-Eichiner, S., S. A. Wolf, and L. E. Drinkwater. 2011. Assessing social-ecological coupling: agriculture and hypoxia in the Gulf of Mexico. Global Environmental Change 21(2):530-539. http://dx.doi.org/10.1016/j.gloenvcha.2010.11.007

Isaac, M. E. 2012. Agricultural information exchange and organizational ties: the effect of network topology on managing agrodiversity. Agricultural Systems 109:9-15. http://dx.doi. org/10.1016/j.agsy.2012.01.011

Isaac, M. E., L. C. N. Anglaaere, D. S. Akoto, and E. Dawoe. 2014. Migrant farmers as information brokers: agroecosystem management in the transition zone of Ghana. Ecology and Society 19(2): 56. http://dx.doi.org/10.5751/es-06589-190256

Isaac, M. E., B. H. Erickson, S. J. Quashie-Sam, and V. R. Timmer. 2007. Transfer of knowledge on agroforestry management practices: the structure of farmer advice networks. Ecology and Society 12(2): 32. [online] URL: http://www.ecologyandsociety. org/vol12/iss2/art32/.

Janssen, M. A., and E. Ostrom. 2006. Empirically based, agentbased models. Ecology and Society 11(2): 37. [online] URL: http:// www.ecologyandsociety.org/vol11/iss $2 / \operatorname{art} 37 /$.

Johnson, J. C., J. J. Luczkovich, S. P. Borgatti, and T. A. B. Snijders. 2009. Using social network analysis tools in ecology: Markov process transition models applied to the seasonal trophic network dynamics of the Chesapeake Bay. Ecological Modelling 220 (22):3133-3140. http://dx.doi.org/10.1016/j.ecolmodel.2009.06.037

Kapoor, I. 2001. Towards participatory environmental management? Journal of Environmental Management 63 (3):269-279. http://dx.doi.org/10.1006/jema.2001.0478

Kashima, Y., S. Wilson, D. Lusher, L. J. Pearson, and C. Pearson. 2013. The acquisition of perceived descriptive norms as social category learning in social networks. Social Networks 35 (4):711-719. http://dx.doi.org/10.1016/j.socnet.2013.06.002

Keizer, K., S. Lindenberg, and L. Steg. 2008. The spreading of disorder. Science 322(5908):1681-1685. http://dx.doi.org/10.1126/ science. 1161405

Krackhardt, D., and J. R. Hanson. 1993. Informal networks: the company behind the chart. Harvard Business Review 71 (1993):104-111.

Lal, R. 2004. Soil carbon sequestration impacts on global climate change and food security. Science 304(5677):1623-1627. http://dx. doi.org/10.1126/science. 1097396 
Lebel, L., T. Grothmann, and B. Siebenhüner. 2010. The role of social learning in adaptiveness: insights from water management. International Environmental Agreements: Politics, Law and Economics 10(4):333-353. http://dx.doi.org/10.1007/s10784-010-9142-6

Lin, N. 2001. Social capital: a theory of social structure and action. Cambridge University Press, Cambridge, UK.

Liu, J., T. Dietz, S. R. Carpenter, M. Alberti, C. Folke, E. Moran, A. N. Pell, P. Deadman, T. Kratz, J. Lubchenco, E. Ostrom, Z. Ouyang, W. Provencher, C. L. Redman, S. H. Schneider, and W. W. Taylor. 2007. Complexity of coupled human and natural systems. Science 317(5844):1513-1516. http://dx.doi.org/10.1126/ science. 1144004

Lubell, M., G. Robins, and P. Wang. 2014. Network structure and institutional complexity in an ecology of water management games. Ecology and Society 19(4): 23. http://dx.doi.org/10.5751/ $\underline{\text { es-06880-190423 }}$

Matous, P. 2013. The making and unmaking of community-based water supplies in Manila. Development in Practice 23(2):217-231. http://dx.doi.org/10.1080/09614524.2013.772116

Matous, P., and Y. Todo. 2015. Exploring dynamic mechanisms of learning networks for resource conservation. Ecology and Society 20(2): 36. http://dx.doi.org/10.5751/es-07602-200236

Matous, P., Y. Todo, and T. Ishikawa. 2014. Emergence of multiplex mobile phone communication networks across rural areas: an Ethiopian experiment. Network Science 2(2):162-188. http://dx.doi.org/10.1017/nws.2014.12

Matous, P., Y. Todo, and D. Mojo. 2013a. Boots are made for walking: interactions across physical and social space in infrastructure-poor regions. Journal of Transport Geography 31:226-235. http://dx.doi.org/10.1016/j.jtrangeo.2013.04.001

Matouš, P., Y. Todo, and D. Mojo. 2013b. Roles of extension and ethno-religious networks in acceptance of resource-conserving agriculture among Ethiopian farmers. International Journal of Agricultural Sustainability 11(4):301-316. http://dx.doi. org/10.1080/14735903.2012.751701

Matous, P., Y. Todo, and A. Pratiwi. 2015. The role of motorized transport and mobile phones in the diffusion of agricultural information in Tanggamus Regency, Indonesia. Transportation, in press. http://dx.doi.org/10.1007/s11116-015-9646-6

Matous, P., T. Tsuchiya, and K. Ozawa. 2011. Farmers' access to resources via networks in remote rural areas with mobile phone reception: creating a resource battery for a mountain tribe in south India. Rural Society Journal 20(2):174-186. http://dx.doi. org/10.5172/rsj.20.2.174

Matson, P. A., W. J. Parton, A. G. Power, and M. J. Swift. 1997. Agricultural intensification and ecosystem properties. Science 277 (5325):504-509. http://dx.doi.org/10.1126/science.277.5325.504

McCormick, S. 2012. After the cap: risk assessment, citizen science, and disaster recovery. Ecology and Society 17(4): 31. http://dx.doi.org/10.5751/es-05263-170431

McPherson, M., L. Smith-Lovin, and J. M. Cook. 2001. Birds of a feather: homophily in social networks. Annual Review of Sociology 27:415-444. http://dx.doi.org/10.1146/annurev.soc.27.1.415
Moeliono, M., C. Gallemore, L. Santoso, M. Brockhaus, and M. Di Gregorio. 2014. Information networks and power: confronting the "wicked problem" of REDD+ in Indonesia. Ecology and Society 19(2): 9. http://dx.doi.org/10.5751/es-06300-190209

Nolan, J. M., P. W. Schultz, R. B. Cialdini, N. J. Goldstein, and V. Griskevicius. 2008. Normative social influence is underdetected. Personality and Social Psychology Bulletin 34 (7):913-923. http://dx.doi.org/10.1177/0146167208316691

Ostrom, E. 1990. Governing the commons: the evolution of institutions for collective action. Cambridge University Press, Cambridge, UK. http://dx.doi.org/10.1017/cbo9780511807763

Pahl-Wostl, C. 2009. A conceptual framework for analysing adaptive capacity and multi-level learning processes in resource governance regimes. Global Environmental Change 19(3):354-365. http://dx.doi.org/10.1016/j.gloenvcha.2009.06.001

Plummer, R., and D. Fennell. 2007. Exploring co-management theory: prospects for sociobiology and reciprocal altruism. Journal of Environmental Management 85(4):944-955. http://dx. doi.org/10.1016/j.jenvman.2006.11.003

Plummer, R., and J. FitzGibbon. 2004. Some observations on the terminology in co-operative environmental management. Journal of Environmental Management 70(1):63-72. http://dx.doi. org/10.1016/j.jenvman.2003.10.005

Prell, C. 2012. Social network analysis: history, theory and methodology. Sage, Thousand Oaks, California, USA.

Prell, C., K. Hubacek, and M. Reed. 2009. Stakeholder analysis and social network analysis in natural resource management. Society and Natural Resources 22(6):501-518. http://dx.doi. org/10.1080/08941920802199202

Pretty, J. 2003. Social capital and the collective management of resources. Science 302(5652):1912-1914. http://dx.doi.org/10.1126/ science. 1090847

Pretty, J., and D. Smith. 2004. Social capital in biodiversity conservation and management. Conservation Biology 18 (3):631-638. http://dx.doi.org/10.1111/j.1523-1739.2004.00126.x

Pretty, J., and H. Ward. 2001. Social capital and the environment. World Development 29(2):209-227. http://dx.doi.org/10.1016/ $\underline{\mathrm{s} 0305-750 \mathrm{x}(00) 00098-\mathrm{x}}$

Prior, T., and C. Eriksen. 2013. Wildfire preparedness, community cohesion and social-ecological systems. Global Environmental Change 23(6):1575-1586. http://dx.doi.org/10.1016/j. gloenvcha.2013.09.016

R Development Core Team. 2008. R: a language and environment for statistical computing. R Foundation for Statistical Computing, Vienna, Austria.

Reed, M. S., A. Graves, N. Dandy, H. Posthumus, K. Hubacek, J. Morris, C. Prell, C. H. Quinn, and L. C. Stringer. 2009. Who's in and why? A typology of stakeholder analysis methods for natural resource management. Journal of Environmental Management 90(5):1933-1949. http://dx.doi.org/10.1016/j. jenvman.2009.01.001

Robins, G., P. Pattison, Y. Kalish, and D. Lusher. 2007. An introduction to exponential random graph $\left(p^{*}\right)$ models for social 
networks. Social Networks 29(2):173-191. http://dx.doi. org/10.1016/j.socnet.2006.08.002

Rodela, R. 2011. Social learning and natural resource management: the emergence of three research perspectives. Ecology and Society 16(4): 30. http://dx.doi.org/10.5751/ es-04554-160430

Rogers, E. M. 2003. Diffusion of innovations. Fifth edition. Free Press, New York, New York, USA.

Schneider, F., P. Fry, T. Ledermann, and S. Rist. 2009. Social learning processes in Swiss soil protection - the 'from farmer - to farmer' project. Human Ecology 37(4): 475-489. http://dx.doi. org/10.1007/s10745-009-9262-1

Scholz, R. W., and F.-W. Wellmer. 2013. Approaching a dynamic view on the availability of mineral resources: What we may learn from the case of phosphorus? Global Environmental Change 23 (1):11-27. http://dx.doi.org/10.1016/j.gloenvcha.2012.10.013

Scott, M. J., R. D. Sands, N. J. Rosenberg, and R. C. Izaurralde. 2002. Future $\mathrm{N}_{2} \mathrm{O}$ from US agriculture: projecting effects of changing land use, agricultural technology, and climate on $\mathrm{N}_{2} \mathrm{O}$ emissions. Global Environmental Change 12(2):105-115. http://dx. doi.org/10.1016/S0959-3780(02)00005-5

Seufert, V., N. Ramankutty, and J. A. Foley. 2012. Comparing the yields of organic and conventional agriculture. Nature 485 (7397):229-232. http://dx.doi.org/10.1038/nature11069

Sikor, T., J. Stahl, T. Enters, J. C. Ribot, N. Singh, W. D. Sunderlin, and L. Wollenberg. 2010. REDD-plus, forest people's rights and nested climate governance. Global Environmental Change 20 (3):423-425. http://dx.doi.org/10.1016/j.gloenvcha.2010.04.007

Solano, C., H. León, E. Pérez, and M. Herrero. 2003. The role of personal information sources on the decision-making process of Costa Rican dairy farmers. Agricultural Systems 76(1):3-18. http://dx.doi.org/10.1016/s0308-521x(02)00074-4

Spielman, D. J., K. Davis, M. Negash, and G. Ayele. 2011. Rural innovation systems and networks: findings from a study of Ethiopian smallholders. Agriculture and Human Values 28 (2):195-212. http://dx.doi.org/10.1007/s10460-010-9273-y

StataCorp. 2009. Stata statistical software: release 11. StataCorp, College Station, Texas, USA.

Tilly, C. 1989. Big structures, large processes, huge comparisons. Russell Sage Foundation, New York, New York, USA.

Tilman, D., J. Fargione, B. Wolff, C. D’Antonio, A. Dobson, R. Howarth, D. Schindler, W. H. Schlesinger, D. Simberloff, and D. Swackhamer. 2001. Forecasting agriculturally driven global environmental change. Science 292(5515):281-284. http://dx.doi. org/10.1126/science.1057544

Trærup, S. L. M. 2012. Informal networks and resilience to climate change impacts: a collective approach to index insurance. Global Environmental Change 22(1):255-267. http://dx.doi.org/10.1016/ j.gloenvcha.2011.09.017

Turner, R. A., N. V. C. Polunin, and S. M. Stead. 2014. Social networks and fishers' behavior: exploring the links between information flow and fishing success in the Northumberland lobster fishery. Ecology and Society 19(2): 38. http://dx.doi. org/10.5751/ES-06456-190238

Vitousek, P. M., H. A. Mooney, J. Lubchenco, and J. M. Melillo. 1997. Human domination of Earth's ecosystems. Science 277 (5325):494-499. http://dx.doi.org/10.1126/science.277.5325.494

Wang, P., G. Robins, and P. Matous. 2016. Multilevel network analysis using ERGM and its extensions. In E. Lazega and T. A. B. Snijders, editors. Multilevel network analysis for the social sciences: theory, methods and applications. Springer, Berlin, Germany, in press.

Wang, P., G. Robins, P. Pattison, and E. Lazega. 2013. Exponential random graph models for multilevel networks. Social Networks 35(1):96-115. http://dx.doi.org/10.1016/j.socnet.2013.01.004

Weiss, K., M. Hamann, M. Kinney, and H. Marsh. 2012. Knowledge exchange and policy influence in a marine resource governance network. Global Environmental Change 22 (1):178-188. http://dx.doi.org/10.1016/j.gloenvcha.2011.09.007

Wolf, J., W. N. Adger, I. Lorenzoni, V. Abrahamson, and R. Raine. 2010. Social capital, individual responses to heat waves and climate change adaptation: an empirical study of two UK cities. Global Environmental Change 20(1):44-52. http://dx.doi. org/10.1016/j.gloenvcha.2009.09.004

Woolcock, M. 1998. Social capital and economic development: toward a theoretical synthesis and policy framework. Theory and Society 27(2):151-208. http://dx.doi.org/10.1023/A:1006884930135

Yamoah, C. F., A. Bationo, B. Shapiro, and S. Koala. 2002. Trend and stability analyses of millet yields treated with fertilizer and crop residues in the Sahel. Field Crops Research 75(1):53-62. http://dx.doi.org/10.1016/s0378-4290(02)00008-4

Young, O. R., F. Berkhout, G. C. Gallopin, M. A. Janssen, E. Ostrom, and S. van der Leeuw. 2006. The globalization of socioecological systems: an agenda for scientific research. Global Environmental Change 16(3):304-316. http://dx.doi.org/10.1016/ j.gloenvcha.2006.03.004 
Appendix 1. Multinomial logistic regression of households' soil management strategies.

Observations

Log likelihood

$-339.47$

$\begin{array}{lll}\text { Coef. } & \text { Std. } & \text { Err. }\end{array}$

Non-users

Internal links

$\begin{array}{lll}0.187 & 0.069 & 0.01\end{array}$

External links

$\begin{array}{lll}-0.369 & 0.185 & 0.05\end{array}$

Reciprocated links

$\begin{array}{lll}-0.281 & 0.184 & 0.13\end{array}$

Finished primary school (1=yes)

$\begin{array}{lll}-1.111 & 0.534 & 0.04\end{array}$

Area of cultivated land [hectares]

$\begin{array}{lll}-0.881 & 0.426 & 0.04\end{array}$

Constant

$\begin{array}{lll}-0.244 & 0.603 & 0.69\end{array}$

Chemical-only

Internal links

$\begin{array}{lll}0.026 & 0.063 & 0.68\end{array}$

External links

$\begin{array}{lll}0.020 & 0.091 & 0.83\end{array}$

Reciprocated links

$\begin{array}{lll}-0.449 & 0.199 & 0.02\end{array}$

Finished primary school (1=yes)

$\begin{array}{lll}0.659 & 0.662 & 0.32\end{array}$

Area of cultivated land [hectares]

$\begin{array}{lll}0.045 & 0.186 & 0.81\end{array}$

Constant

$\begin{array}{lll}-1.551 & 0.700 & 0.03\end{array}$

Organic-only

Internal links

External links

$\begin{array}{lll}0.062 & 0.061 & 0.31\end{array}$

Reciprocated links

$\begin{array}{lll}0.085 & 0.085 & 0.32\end{array}$

$-0.273 \quad 0.173 \quad 0.11$

Finished primary school (1=yes)

$\begin{array}{lll}1.001 & 0.781 & 0.20\end{array}$

Area of cultivated land [hectares]

$\begin{array}{lll}-0.266 & 0.227 & 0.24\end{array}$

Constant

$\begin{array}{lll}-1.953 & 0.814 & 0.02\end{array}$

Combined users

(base outcome) 